\title{
SOSIALISASI DAN PELATIHAN PIJAT BAYI
}

\author{
Juli Selvi Yanti, SST, M.Kes ${ }^{(1)}$, Een Husanah, SKM, M.Kes ${ }^{(2)}$ \\ ${ }^{(1),(2)}$ STIKes Hang Tuah Pekanbaru \\ Email: juliselviyanti.jsy@ htp.ac.id
}

\begin{abstract}
ABSTRAC
Baby massage is a direct contact therapy with the body that can provide a feeling of security and comfort to babies. The touch and hug of a mother is a basic need of a baby. If the baby massage is carried out regularly, it will increase catecholamine hormones (epinephrine and norepinephrine) which can stimulate growth and development because it can increase appetite, increase body weight, and stimulate the development of brain structure and function (Riksani, 2012).

Baby massage is a direct contact therapy with the body that can provide a feeling of security and comfort to babies. The touch and hug of a mother is a basic need of a baby. If the baby massage is carried out regularly, it will increase catecholamine hormones (epinephrine and norepinephrine) which can stimulate growth and development because it can increase appetite, increase body weight, and stimulate the development of brain structure and function (Riksani, 2012).
\end{abstract}

Keywords: Baby Massage, Kelurahan Maharani

\begin{abstract}
ABSTRAK
Pijat bayi merupakan terapi sentuh kontak langsung dengan tubuh yang dapat memberikan rasa aman dan nyaman pada bayi. Sentuhan dan pelukan dari seorang ibu adalah kebutuhan dasar bayi. Jika pijat bayi dilakukan secara teratur akan meningkatkan hormon katekolamin (epinefrin dan norepinefrin) yang dapat memicu stimulasi tumbuh kembang karena dapat meningkatkan nafsu makan, meningkatkan berat badan, dan merangsang perkembangan struktur maupun fungsi otak (Riksani, 2012).

Pijat bayi merupakan terapi sentuh kontak langsung dengan tubuh yang dapat memberikan rasa aman dan nyaman pada bayi. Sentuhan dan pelukan dari seorang ibu adalah kebutuhan dasar bayi. Jika pijat bayi dilakukan secara teratur akan meningkatkan hormon katekolamin (epinefrin dan norepinefrin) yang dapat memicu stimulasi tumbuh kembang karena dapat meningkatkan nafsu makan, meningkatkan berat badan, dan merangsang perkembangan struktur maupun fungsi otak (Riksani, 2012).
\end{abstract}

Kata Kunci: Pijat Bayi, Kelurahan Maharani 


\section{PENDAHULUAN}

Pijat bayi selain membantu tumbuh kembang fisik dan emosi bayi, juga dapat mempererat hubungan antara ibu dan si buah hati. Tanpa diketahui ketika memandikan bayi, mengeringkan tubuhnya dengan menggosok punggungnya atau bermain-main dengan memijat kakinya, sebenarnya banyak rangsangan yang diberikan padanya. Memberikan rangsangan pada bayi memang banyak caranya, salah satu diantaranya melalui pijatan (stroking) (Kalbe Farma, 2001).

Pijat bayi selain membantu tumbuh kembang fisik dan emosi bayi, juga dapat mempererat hubungan antara ibu dan si buah hati. Tanpa diketahui ketika memandikan bayi, mengeringkan tubuhnya dengan menggosok punggungnya atau bermain-main dengan memijat kakinya, sebenarnya banyak rangsangan yang diberikan padanya. Memberikan rangsangan pada bayi memang banyak caranya, salah satu diantaranya melalui pijatan (stroking) (Kalbe Farma, 2001).

Namun pengetahuan tentang pijat bayi ini masih belum diketahui oleh masyarakat, dikarenakan masyarakat masih mempercayakan pijat bayi kepada dukun bayi dan kurangnya pengetahuan masyarakat untuk melakukan pijat bayi kepada tenaga kesehatan. Faktor lain yang menyebabkan masyarakat lebih memilih pijat bayi kepada dukun bayi adalah faktor adat istiadat yang masih di pegang teguh dan berkembang secara turun temurun.

\section{METODE KEGIATAN}

Dalam kegiatan pengabdian ini metode yang digunakan adalah penyuluhan dan demonstrasi atau praktik pelaksanaan pijat bayi. Materi yang diberikan dalam penyuluhan adalah tentang manfaat pijat bayi pada bayi. Pelaksanan demonstrasi atau praktik pelaksanaan dilakukan sesuai dengan teknik pijat bayi pada bayi

\section{HASIL DAN PEMBAHASAN}

\section{Hasil Pelaksanaan}

Kegiatan penyuluhan dan pelaksanaan praktek pijat bayi ini telah dilaksanakan pada 28 November 2019 di Kelurahan maharani kec.Rumbai Kota Pekanbaru kepada 32 orang ibu dan 20 bayi yang diberi perlakuan pijat bayi.

Berdasarkan pengamatan selama kegiatan berlangsung, kegiatan pegabdian pada masyarakat ini memberikan hasil sebagai berikut :

1. Meningkatnya pengetahuan dan pemahaman ibu-ibu tentang pijat bayi, pengertian pijat bayi, manfaat pijat bayi dan tujuan pijat bayi. Hal ini dapat dilihat dari kemampuan ibu 
yang mampu menjawab pertanyaanpertanyaan yang diberikan pemateri.

2. Meningkatnya rasa ibu untuk menemukan solusi tentang keresahan dan susah tidur yang dialami bayinya dimana ibu mampu melaksankan pijat bayi setelah dilakukan demotrasi.

\section{PEMBAHASAN}

Kegiatan penyuluhan dan pelaksanaan praktek pijat bayi di Kelurahan Maharani Kecamatan Rumbai berjalan dengan sangat baik.Hal ini terlihat dari antusias nya para ibu dan bayi yang hadir pada saat kegiatan berlangsung banyak para ibu bertanya menunjukkan rasa ingin tahu mereka terhadap materi yang disampaikan. Selama ini, penegetahuan ibu tentang pijat bayi masih sangat kurang. Sehingga setelah diberikan penyuluhan para ibu mengerti pentingnya pijat bayi dan bagaimana melaksanakan pijat bayi yang aman.

Dalam mengatasi masalah keresahan dan susah tidur yang dialami bayinya, bisa dicegah dengan memberikan edukasi ataupun praktek langsung kepada ibu dan bayi pelaksanaan pijat bayi'

\section{KESIMPULAN}

Dari pembahasan diatas dapat disimpulkan bahwa pijat bayi merupakan salah satu cara yang menyenangkan yang akan membuat perasaan nyaman bagi bayi. Karena pijatan lembut akan membantu meringankan ketegangan otot sehingga bayi menjadi tenang.

Jadi pijat bayi sangat penting serta berguna dalam memberikan suatu kenyamanan yang di butuhkan oleh bayi.

\section{DAFTAR PUSTAKA}

Aditya, N. (2014). Handbook For New Mom. Yogyakarta: Stiletto Book Andriana, D. (2011). Tumbuh Kembang \& Terapi Bermain pada Anak. Jakarta: Medika

Fitriani \& Nurhidayanti. (2017). Pengaruh Teknik Pijat Bayi Terhadap Kenaikan Berat Badan Usia 0-6 bulan. Jurnal Midpro. Volume 9. No 2

Riksani, Ria. (2012). Cara Mudah dan Aman Pijit Bayi. Jakarta : Dunia Sehat Roesli, Utami.(2009). Pedoman Pijit Bayi. Jakarta : PT. Trubus Agri Widia

Setiawan, A. (2010). Metodologi Penelitian Kebidanan. Yogyakarta : Nuha Medika

Subakti, D. (2008). Keajaiban Pijit Bayi dan Balita. Jakarta : Wahyu Medika Suparyanto. (2011). Perkembangan Anak. Jakarta : Prenada Media Group Yanti, F \& Mardianti. (2014). Peningkatan Berat Badan Bayi Melalui Pijat Bayi. Jurnal Kebidanan Indonesia. Volume 17 No 1 Hal 25-29, 1410-4490 